\title{
Amino acids profiles of six dinoflagellate species belonging to diverse families: possible use as animal feeds in aquaculture
}

\author{
An Suk Lim ${ }^{1,2}$, Hae Jin Jeong ${ }^{1,3, *}$, So Jin Kim $^{1}$ and Jin Hee Ok ${ }^{1}$ \\ ${ }^{1}$ School of Earth and Environmental Sciences, College of Natural Sciences, Seoul National University, Seoul 08826, Korea \\ ${ }^{2}$ Brain Korea 21 plus program, School of Earth and Environmental Sciences, College of Natural Sciences, Seoul National \\ University, Seoul 08826, Korea \\ ${ }^{3}$ Advanced Institutes of Convergence Technology, Suwon 16229, Korea
}

\begin{abstract}
Microalgae have been utilized in diverse industries including aquaculture. Among the microalgae, dinoflagellates are known to have various bioactive compounds, and thus the interest in their application to industry has increased. In order to test their potential as food materials for aquaculture animals, the crude protein contents and compositions of amino acids of six dinoflagellates Heterocapsa rotundata (family Heterocapsaceae), Ansanella granifera (Suessiaceae), Alexandrium andersonii (Ostreopsidaceae), Takayama tasmanica (Brachidiniaceae), Takayama helix, and Gymnodinium smaydae (Gymnodiniaceae) belonging to diverse families were analyzed. The percentage of the amount of the crude protein relative to dry weight of T. tasmanica was the highest (65\%) and that of A. andersonii was the lowest (26\%). However, the highest percentage of total detected amino acids in crude protein was found in A. andersonii (98.2\%). In all six dinoflagellates, glutamic acid was the most dominant amino acid in crude protein. However, the second main amino acid was aspartic acid for H. rotundata, A. granifera, T. helix, and G. smaydae, but were arginine and leucine for A. andersonii and T. tasmanica, respectively. Furthermore, T. tasmanica and T. helix did not have taurine and gammaaminobutyric acid, whereas the other dinoflagellates possessed them. The percentages of essential amino acid contents of the dinoflagellates met the requirement levels for juvenile shrimps. In addition, the dinoflagellates were not toxic to the brine shrimp Artemia salina. Compared with the other microalgae reported so far, H. rotundata and A. andersonii can be used for arginine-rich diets, T. tasmanica for valine and leucine-rich diets, A. granifera for histidine-rich diets, $T$. helix for threonine-rich diets, and G. smaydae for lysine-rich diets. Therefore, based on their biochemical composition and toxicity to Artemia, the dinoflagellates could be used as essential amino acid sources for cultivating animals in the aquaculture industry.
\end{abstract}

Key Words: algae; biomass; high-performance liquid chromatography; protein; shrimp farming

\section{INTRODUCTION}

Microalgae are unicellular, eukaryotic organisms, and an evolutionarily diverse group containing approximately 200,000 species (Norton et al. 1996, Singh and Saxena 2015). Microalgae have been used as diverse biological resources and are also treated as one of the most promising sources for new high-value products and applications (Pulz and Gross 2004, Jang et al. 2017). Thus, several species are currently exploited for a variety of biotech-
(1) $\$$ This is an Open Access article distributed under the terms of the Creative Commons Attribution Non-Commercial License (http://creativecommons.org/licenses/by-nc/3.0/) which permits unrestricted non-commercial use, distribution, and reproduction in any medium, provided the original work is properly cited.
Received July 19, 2018, Accepted September 10, 2018

*Corresponding Author

E-mail: hjjeong@snu.ac.kr

Tel: +82-2-880-6746, Fax: +82-2-874-9695 
nological purposes, including cosmeceuticals, animal feed, functional foods, fatty acids, other biologically active compounds, wastewater treatment, and biofuel (Fabregas and Herrero 1985, Becker 2004, Pulz and Gross 2004, Spolaore et al. 2006, Matos et al. 2017). Microalgae have some important advantages over conventional land plants because they can be produced all year around and have greater biomass productivity (Singh and Gu 2010, Buono et al. 2014). The microalgal biomass in the world has been estimated at a value of US $\$ 1.25 \times 10^{9}$ per year and produces 5,000 tons $\mathrm{y}^{1}$ of dry matter (Pulz and Gross 2004). However, the biochemical compositions of microalgal are very diverse and depend on the species (Andersen 2013). Therefore, successful algal biotechnology mainly depends on choosing the right algal species with relevant properties for specific purposes (Pulz and Gross 2004). Thus, the selection, isolation, and study of new candidate microalgal species that may possess unique functional ingredients are needed.

Several microalgal species have been utilized in aquaculture as important food sources or food additives for aquaculture animals such as mollusks, shrimp, rotifers, and fish (Borowitzka 1997, Bleakley and Hayes 2017). To produce $3.8 \times 10^{6}$ tons of shrimps globally in 2010, 612 tons of microalgae (in dry weight) were estimated to be required (Muller-Feuga 2013). Over 20 years, several microalgal genera such as the chlorophyte Chlorella, prasinophyte Tetraselmis, prymnesiophytes Isochrysis, Pavlova, bacillariophytes Phaeodactylum, Chaetoceros, Skeletone$m a$, Thalassiosira, and eustigmatophyte Nannochloropsis have been used in aquaculture either as individual diets or components of mixed diets (Brown 2002, Spolaore et al. 2006, Hemaiswarya et al. 2011, Roy and Pal 2015). However, to increase production of aquaculture animals, more effort is required to discover new microalgal species with higher nutritional quality. In particular, to use a microalgal species as a source of aquaculture feed, it should be easy to culture, does not produce toxic materials, but has highly nutritious proteins (Hemaiswarya et al. 2011).

Shrimps cannot synthesize all amino acids and thus they must obtain some amino acids from their diet. The amino acids that an organism cannot synthesize on its own (or are incapable of synthesizing sufficient amounts) are referred to as essential amino acids (National Research Council 2011). Arginine, histidine, isoleucine, leucine, lysine, methionine, phenylalanine, threonine, tryptophan, and valine are essential amino acids that are required in diets for shrimps (National Research Council 2011). Moreover, taurine may be conditionally essential for some juvenile marine fish and shrimp (National Re- search Council 2011). Furthermore, some salmonoids, shrimp, and lobsters need to consume carotenoid pigments such as astaxanthin and canthaxanthin which causes the pink color in their flesh (Gouveia et al. 2008, Bleakley and Hayes 2017). Therefore, the microalgal species which satisfy such requirements can be used for animal feeds.

Dinoflagellates live in freshwater and marine waters (Taylor et al. 2008). They are a major component of diverse marine ecosystems and play diverse roles as primary producer, predator, prey, and symbiotic partners in marine ecosystems (Jeong et al. 2010, 2015, Holmes et al. 2014, LaJeunesse et al. 2018). They also contain diverse useful materials such as omega-3, macrolides, mycosporine-like amino acids, and carotenoids (Shimizu 1996, Mendes et al. 2009, Rosic and Dove 2011, Onodera et al. 2014, Jang et al. 2017). However, only few dinoflagellate species have been studied for their amino acid compositions (Okaichi 1974, Hayashi et al. 1986, Flynn and Flynn 1992, Markell and Trench 1993), and their potential as a food source in aquaculture has been rarely studied (Sánchez 1986). To the best our knowledge, among dinoflagellates, only Gymnodinium sp. and Crypthecodinium cohnii have been used as a food material for aquatic animals (Harel and Clayton 2004, Pulz and Gross 2004, Gouveia et al. 2008, Muller-Feuga 2013). Therefore, more dinoflagellate species should be studied to develop new effective species for the aquaculture industry.

In the present study, the crude protein (CP) contents and compositions of amino acids of six dinoflagellate species, Heterocapsa rotundata, Ansanella granifera, Alexandrium andersonii, Takayama tasmanica, Takayama helix, and Gymnodinium smaydae, were analyzed. These dinoflagellates belong to diverse families such as Heterocapsaceae, Suessiaceae, Ostreopsidaceae, Brachidiniaceae, and Gymnodiniaceae (Guiry and Guiry 2018). Thus, it is worthwhile to test whether they have the $\mathrm{CP}$ contents and compositions of amino acids similar to each other or not, although their taxonomical distances are large. Moreover, the levels of essential amino acid of the dinoflagellates were compared to the requirement levels of essential amino acid for juvenile shrimps. Based on the average requirement of essential amino acids, essential amino acid indexes of the dinoflagellates were determined. Furthermore, nutritional values of dinoflagellates were compared to those of other microalgae, which are frequently used for aquaculture. The results of this study provide the biochemical profiles of dinoflagellates belonging to diverse families and allow the possibility to use them as a protein source for aquaculture. 


\section{MATERIALS AND METHODS}

\section{Preparation of experimental organisms}

The dinoflagellates $H$. rotundata (HRSH1201) and $A$. granifera (AGSW10) were isolated from the surface water or sediment samples of Shiwha Bay, Korea in January 2012 and September 2010, respectively (Table 1). The dinoflagellate A. andersonii (AAJH1505) was isolated from Jinhae Bay, Korea in May 2015. These clonal cultures were established following two serial single-cell isolations (Jeong et al. 2014, Lee et al. 2016). Furthermore, the mixotrophic dinoflagellate G. smaydae (GSSW10) was isolated from Shiwha Bay, Korea in May 2010 (Table 1). A clonal culture of G. smaydae was established by providing H. rotundata as prey. Moreover, T. helix (CCMP3082) was obtained from the National Center for Marine Algae and Microbiota, USA and T. tasmanica (CAWD115) was obtained from the Cawthron Institute's Culture Collection of Microalgae, New Zealand.

\section{Cell culturing and harvesting}

To obtain large volumes of $H$. rotundata, A. granifera, A. andersonii, T. tasmanica, and T. helix, a clonal culture of each species was maintained in enriched $\mathrm{f} / 2$-Si seawater media (Guillard and Ryther 1962) in 2-L polycarbonate bottles at $20^{\circ} \mathrm{C}$ under an illumination of $50 \mu \mathrm{mol} \mathrm{m} \mathrm{m}^{-2}$ $\mathrm{s}^{-1}$ provided by cool white fluorescent light on a $14: 10 \mathrm{~h}$ light : dark cycle. However, the culture of G. smaydae was mixotrophically cultured by continuously providing $H$. rotundata as a prey species (ca. 30,000-50,000 cells $\mathrm{mL}^{-1}$ ) every two days. The bottles of $G$. smaydae culture were also maintained under the temperature and light conditions described above.
To determine the growth rate of each dinoflagellate species, a 5-mL aliquot was removed from each bottle every two days, or before and after providing prey cells. The samples were fixed with 5\% Lugol's solution, and all or $>200$ cells in three 1-mL Sedgwick-Rafter chamber were enumerated. When the growth reached the early-stationary phase, the alga was collected by continuous centrifugation at 4,000 rpm and stored at $-70^{\circ} \mathrm{C}$ in the deep freezer until analyzed. When the cultures were harvested, the final density and concentrated volume of each culture was determined to calculate the total number of the cells.

\section{$\mathrm{CP}$ and amino acid analysis}

The frozen concentrated samples were dried at $-70^{\circ} \mathrm{C}$. Triplicated samples were analyzed except $A$. granifera, which were analyzed in duplicates. The CP was calculated as total nitrogen in each sample multiplied by a factor of 4.78, which was developed for marine microalgae (Lourenço et al. 2004). Total nitrogen was determined by multiplying the nitrogen content of a cell with the total number of cells in each sample. The nitrogen content of a cell was calculated from the Menden-Deuer and Lessard equation used to convert cell volume to nitrogen content for dinoflagellates (Menden-Deuer and Lessard 2000). To calculate the cell volume, cell size was measured based on >20 randomly selected cells using an inverted light microscope (Carl Zeiss Axiovert 200M; Carl Zeiss Microscopy GmbH, Jena, Germany). The volume of $H$. rotundata, T. tasmanica, and T. helix cells in cultures was estimated with the equation for a rotational ellipsoid, while that of $A$. andersonii cells was estimated with the equation for a sphere. Moreover, the volume of A. granifera and $G$. smaydae was obtained from our previous studies (Lee et al. 2014a, 2014b).

Table 1. Information on the isolation and culturing of the strains of the dinoflagellates used in this study

\begin{tabular}{|c|c|c|c|c|c|c|}
\hline Species & Date & Area & $\begin{array}{c}\text { Water } \\
\text { temperature }\left({ }^{\circ} \mathrm{C}\right)\end{array}$ & Salinity & Culture condition & Reference \\
\hline $\begin{array}{l}\text { Heterocapsa rotundata } \\
\text { (HRSH1201) }\end{array}$ & Jan 2012 & $\begin{array}{l}\text { Shiwha Bay, } \\
\text { Korea }\end{array}$ & 0.2 & 31.0 & Phototrophic & $\begin{array}{l}\text { Lee et al. } \\
(2016)\end{array}$ \\
\hline $\begin{array}{l}\text { Ansanella granifera } \\
\text { (AGSW10) }\end{array}$ & Sep 2010 & $\begin{array}{l}\text { Shiwha Bay, } \\
\text { Korea }\end{array}$ & 23.1 & 15.6 & Phototrophic & $\begin{array}{l}\text { Jeong et al. } \\
\text { (2014) }\end{array}$ \\
\hline $\begin{array}{l}\text { Alexandrium andersonii } \\
\text { (AAJH1505) }\end{array}$ & May 2015 & $\begin{array}{l}\text { Jinhae Bay, } \\
\text { Korea }\end{array}$ & 15.3 & 27.4 & Phototrophic & $\begin{array}{l}\text { Lee et al. } \\
\text { (2016) }\end{array}$ \\
\hline $\begin{array}{l}\text { Takayama tasmanica } \\
\text { (CAWD115) }\end{array}$ & Dec 2000 & $\begin{array}{l}\text { Glenhaven, } \\
\text { New Zealand }\end{array}$ & NA & NA & Phototrophic & - \\
\hline $\begin{array}{l}\text { Takayama helix } \\
\text { (CCMP3082) }\end{array}$ & May 2001 & $\begin{array}{l}\text { Tasman Sea, } \\
\text { Australia }\end{array}$ & 16 & 30 & Phototrophic & - \\
\hline $\begin{array}{l}\text { Gymnodinium smaydae } \\
\text { (GSSW10) }\end{array}$ & May 2010 & $\begin{array}{l}\text { Shiwha Bay, } \\
\text { Korea }\end{array}$ & 19 & 27.7 & Mixotrophic $^{\mathrm{a}}$ & $\begin{array}{l}\text { Kang et al. } \\
\quad(2014)\end{array}$ \\
\hline
\end{tabular}

${ }^{a}$ Cultured mixtrophically by providing Heterocapsa rotundata as prey because it does not grow by photosynthesis alone.

NA, not available. 
The 20-40 mg of each sample was hydrolyzed in 6 $\mathrm{N} \mathrm{HCl}$ at $130^{\circ} \mathrm{C}$ for $24 \mathrm{~h}$ for analyzing the amino acids. Amino acid profiling included analysis of the following essential and non-essential amino acids: histidine, isoleucine, leucine, lysine, methionine, phenylalanine, threonine, valine, serine, aspartic acid, glutamic acid, arginine, glycine, alanine, proline, tyrosine, taurine, and gamma-aminobutyric acid. However, tryptophan and cysteine were not obtained because they are completely lost with acid hydrolysis, and methionine was not fully obtained because it could be destroyed to varying degrees with acid hydrolysis (Lourenço et al. 2004). Thus, in the present study, tryptophan and cysteine were omitted and the value for methionine could be underestimated. The amino acids were analyzed using Ultimate 3000 High Performance Liquid Chromatography (HPLC/Fluorescence model; Thermo Fisher Scientific, Waltham, MA, USA).

The amount of each amino acid was expressed as a percentage in CP or a percentage in the analyzed total amino acids in the present study. The essential amino acid index (EAAI) is a common index for estimating the quality of a given protein (Oser 1959, Becker 2004).

The EAAI of a dinoflagellate was determined from the formula:

$$
\text { EAAI }=\sqrt[n]{\frac{\mathrm{aa}_{1}}{\mathrm{AA}_{1}} \times \frac{\mathrm{aa}_{2}}{\mathrm{AA}_{2}} \times \frac{\mathrm{aa}_{3}}{\mathrm{AA}_{3}} \times \frac{\mathrm{aa}_{4}}{\mathrm{AA}_{4}} \times \ldots . . \times \frac{\mathrm{aa}_{\mathrm{n}}}{\mathrm{AA}_{\mathrm{n}}}}
$$

, where $\mathrm{aa}_{1}, \ldots, \mathrm{aa}_{\mathrm{n}}$ are the amino acid contents of a dinoflagellate and $\mathrm{AA}_{1}, \ldots, \mathrm{AA}_{\mathrm{n}}$ are the average required levels of these amino acids in juvenile shrimps.

The geometric mean, EAAI should be the ratio of all essential amino acids of a dinoflagellate to those of whole egg (Oser 1959). However, EAAI has been modified and used with various standard proteins in the previous studies (Brown 1991, Brown and Jeffrey 1992, Becker 2004), and thus the essential amino acid requirements for juvenile shrimp served as a standard for evaluating the quality of protein in the dinoflagellate in the present study. The juveniles of the prawn Penaeus japonicus and Penaeus monodon were chosen as the standard animals representing each requirement level of essential amino acids (EAAs) because they are the major groups of shrimp used in the aquaculture industry (Madrigal et al. 2017). Because methionine could be partially destroyed during the acid hydrolysis, eight essential amino acids, histidine, threonine, arginine, valine, phenylalanine, isoleucine, leucine, and lysine were used to determine EAAI. Moreover, in the evaluation, a EAAI score of $>0.95$ defined a 'high' quality of protein, while a score of 0.86-0.95 signified a 'good' quality protein, a score of 0.75-0.86 signified a 'useful' protein, and a score of $\leq 0.75$ indicated an 'inadequate' protein (Zhang et al. 2009).

The amino acid showing the greatest difference in percentage from its required level is the limiting amino acid.

\section{Artemia test for toxicity}

A bioassay for potential toxicity of each of the six dinoflagellates tested was conducted using the brine shrimp Artemia salina. Encysted eggs of A. salina were hatched in $500 \mathrm{~mL}$ of filtrated natural seawater under artificial light at $20^{\circ} \mathrm{C}$ for $48 \mathrm{~h}$. Six-well plate chambers were prepared with triplicate wells of several densities of each dinoflagellate and 10 A. salina nauplii were placed in each well of the plate chambers. The experimental densities were 100, 1,000, 5,000, 10,000, 100,000, and 200,000 cells $\mathrm{mL}^{-1}$ for $H$. rotundata and A. granifera, 10, $100,1,000,2,000$, and 5,000 cells $\mathrm{mL}^{-1}$ for T. tasmanica, 10 , $100,1,000,2,000$, and 4,000 cells $\mathrm{mL}^{-1}$ for T. helix, and 100 , 1,000, 5,000, 10,000, and 20,000 cells $\mathrm{mL}^{-1}$ for G. smaydae. In addition, triplicate wells containing a mixture of 10 nauplii and each dinoflagellate-filtrate as well as triplicate wells containing 10 nauplii only were established. The filtrate was obtained through filtration (Whatman grade GF/C filter; GE Healthcare, Buckinghamshire, UK) of each dense culture. As a positive control, 7,000 cells $\mathrm{mL}^{-1}$ of Alexandrium minutum was used in an identical experimental setup (Lim et al. 2015). The plate chambers were incubated at $20^{\circ} \mathrm{C}$ under a $14: 10 \mathrm{~h}$ light : dark cycle of cool white fluorescent lights at $20 \mu \mathrm{mol} \mathrm{m} \mathrm{m}^{-2} \mathrm{~s}^{-1}$. At the beginning of the incubation and 6, 12, 24, and $48 \mathrm{~h}$ later, the plate chambers were placed under a dissecting microscope, and living and dead nauplii were counted at a magnification of $\times 7-40$.

\section{RESULTS}

\section{$\mathrm{CP}$ and amino acid composition}

The CP of six dinoflagellates tested in the present study ranged from 26 to $65 \%$ of dry mass (Table 2, Fig. 1A). The percentage of the amount of CP relative to dry weight of T. tasmanica was the highest (65\%), that of $H$. rotundata, A. granifera, T. helix, and G. smaydae the second highest (53-63\%), and A. andersonii the lowest (26\%).

In the composition of amino acids, the top 5 amino acids were the same in $H$. rotundata, $A$. granifera, $A$. an- 

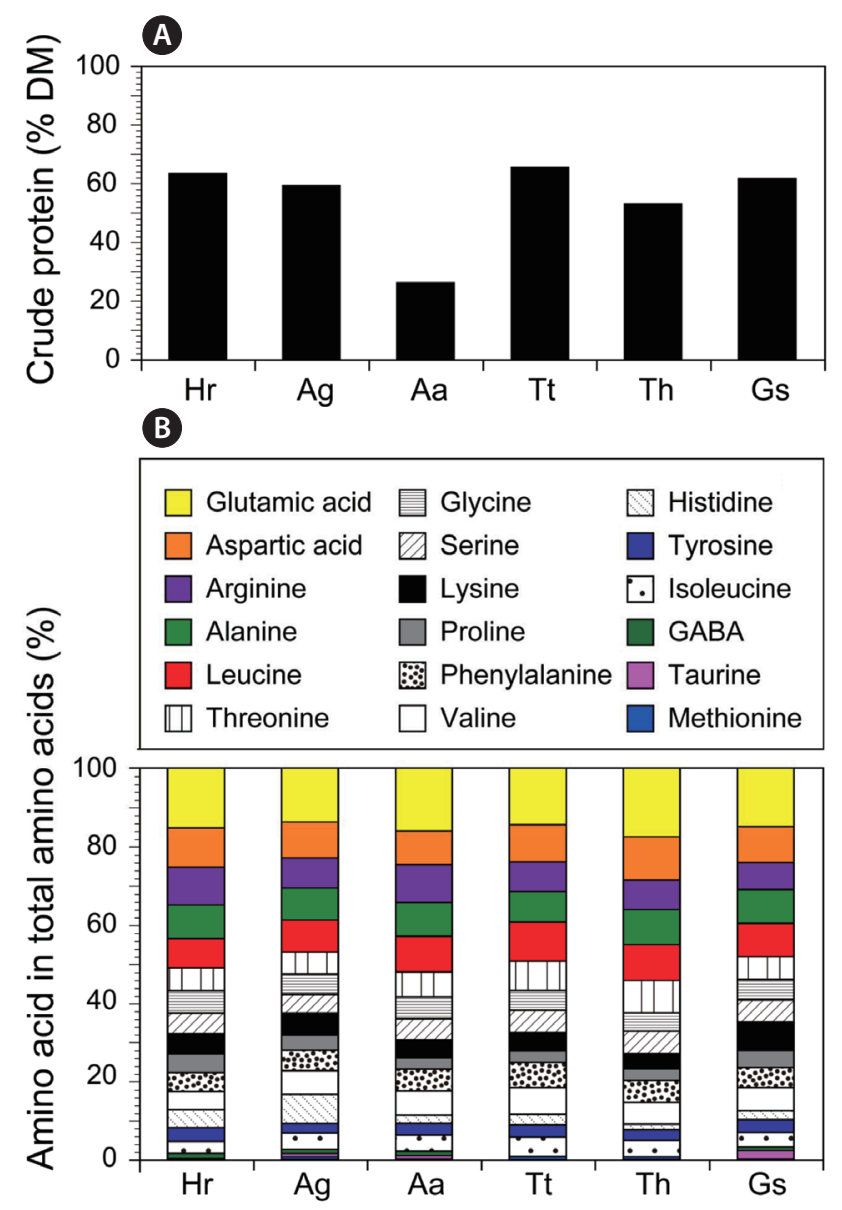

Fig. 1. Percentage of crude protein in dry mass (DM) (A) and the percentage of each amino acid to total detected amino acids of the dinoflagellates (B). Hr, Heterocapsa rotundata; Ag, Ansanella granifera; Aa, Alexandrium andersonii; Tt, Takayama tasmanica; Th, Takayama helix; Gs, Gymnodinium smaydae; GABA, gamma-aminobutyric acid. Methionine was either not detected or detected in trace amounts because of the hydrolytic condition. dersonii, and T. tasmanica; glutamic acid, aspartic acid, arginine, alanine, and leucine (Fig. 1B). Moreover, the top four amino acids, glutamic acid, aspartic acid, alanine, and leucine, were the same in T. helix and G. smaydae (Fig. 1B). In all six dinoflagellates, glutamic acid was the most dominant amino acid in CP, ranging from 7.4 to $15.8 \%$ (Table 3 ). The second main amino acid was aspartic acid for H. rotundata, A. granifera, T. helix, and G. smaydae, whereas arginine and leucine were the second main amino acids for A. andersonii and T. tasmanica, respectively (Table 3, Fig. 1B). Moreover, taurine and gamma-aminobutyric acid were detected in $H$. rotundata, A. granifera, A. andersonii, and G. smaydae although its percentages in CP were as low as $<1 \%$. However, these two amino acids were not detected in T. tasmanica and T. helix (Table 3).

Regarding the EAAs, the percentage of histidine in $\mathrm{CP}$ was the highest in A. granifera, whereas the percentages of threonine, arginine, valine, phenylalanine, isoleucine, leucine, and lysine in CP were the highest in A. andersonii (Fig. 2). The percentage of total detected amino acids (TDAAs) in CP varied from 50.1 to $98.2 \%$; the lowest percentage was found in G. smaydae, while the highest percentage was in A. andersonii (Table 3). The nonessential amino acids of $H$. rotundata, $A$. andersonii, T. helix, and G. smaydae were greater than their EAAs, whereas those of A. granifera and T. tasmanica were slightly lower than their EAAs (Table 3).

\section{Evaluation of amino acids as animal feed in aquaculture}

The percentage of each EAA of each of the six dinoflagellate species was greater or lower than that required for the juvenile shrimps (Table 3, Fig. 3); the percent-

Table 2. Nitrogen content and crude protein of each dinoflagellate

\begin{tabular}{lccc}
\hline \multicolumn{1}{c}{ Species } & $\begin{array}{c}\text { Cell volume } \\
\left(\mu^{3}\right)\end{array}$ & $\begin{array}{c}\text { Nitrogen content } \\
(\mathbf{p g ~ N ~ p e r ~ c e l l ) ~}\end{array}$ & $\begin{array}{c}\text { Crude protein } \\
(\% \text { dry mass })\end{array}$ \\
\hline Heterocapsa rotundata & 284 & 14 & 63 \\
Ansanella granifera & $492^{\mathrm{a}}$ & 23 & 59 \\
Alexandrium andersonii & 1,731 & 66 & 26 \\
Takayama tasmanica & 3,990 & 135 & 65 \\
Takayama helix & 5,473 & 176 & 53 \\
Gymnodinium smaydae & $340^{\mathrm{b}}$ & 17 & 61 \\
\hline
\end{tabular}

Crude protein is expressed as a percentage of dry mass. Nitrogen content per cell of each species was calculated from cell volume using the equation of Menden-Deuer and Lessard (2000).

${ }^{\mathrm{a}}$ Data obtained from Lee et al. (2014b).

${ }^{\mathrm{b}}$ Data obtained from Lee et al. (2014a). 

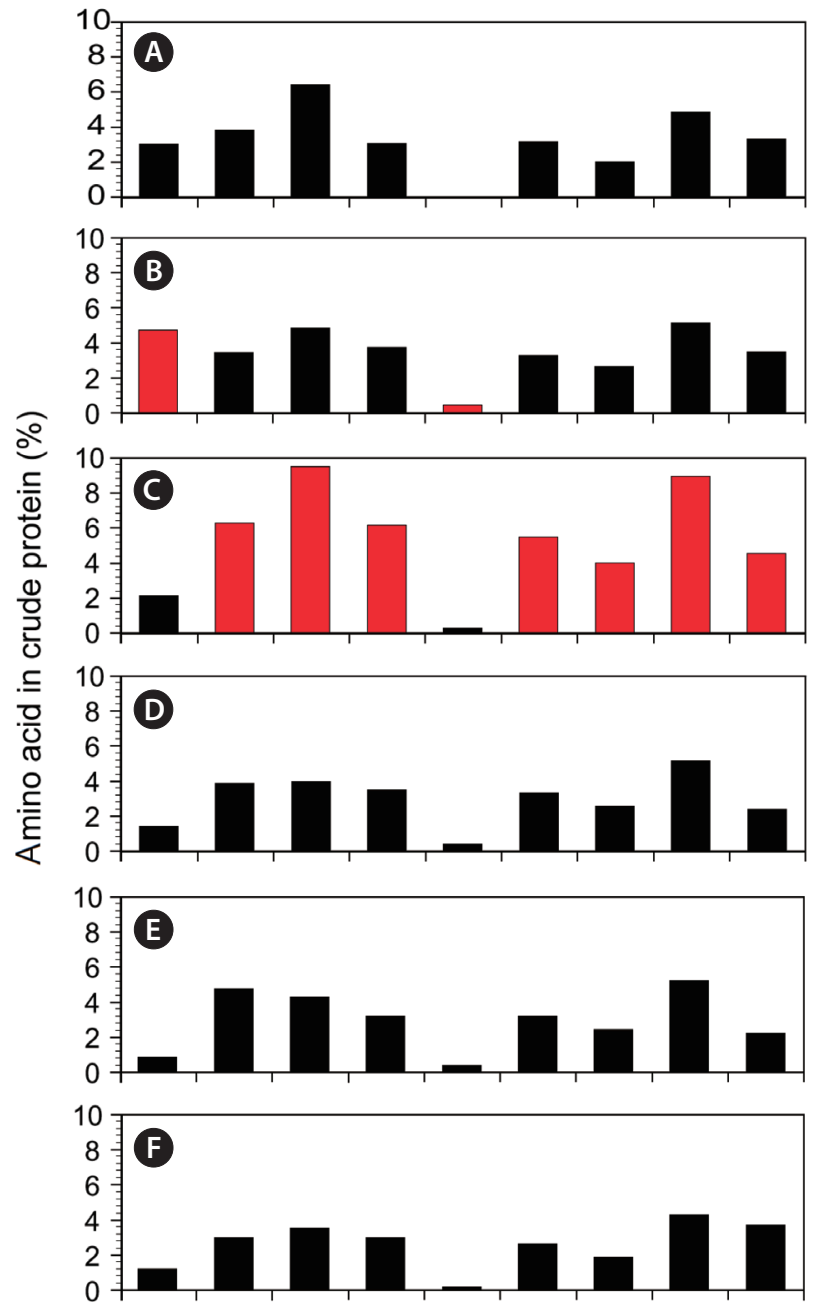

His Thr Arg Val Met Phe Iso Leu Lys

Essential amino acid

Fig. 2. Percentage of each essential amino acid in crude protein of the dinoflagellates. (A) Heterocapsa rotundata. (B) Ansanella granifera. (C) Alexandrium andersonii. (D) Takayama tasmanica. (E) Takayama helix. (F) Gymnodinium smaydae. His, hitstidine; Thr, threonine; Arg, arginine; Val, valine; Met, methionine; Phe, phenylalanine; Iso, isoleucine; Leu, leucine; Lys, lysine. Red bars indicate the dinoflagellate species which as the highest value of each essential amino acid.

ages of all EAA except lysine of $A$. andersonii were greater than those required, whereas the percentages of all EAA of G. smaydae were lower than those required. In $\mathrm{H}$. rotundata, the percentages of histidine and arginine were greater than those required, whereas those of isoleucine and lysine were lower than those required (Fig. 3A). In $A$. granifera, the percentage of histidine was much greater than those required, whereas those of isoleucine and ly-

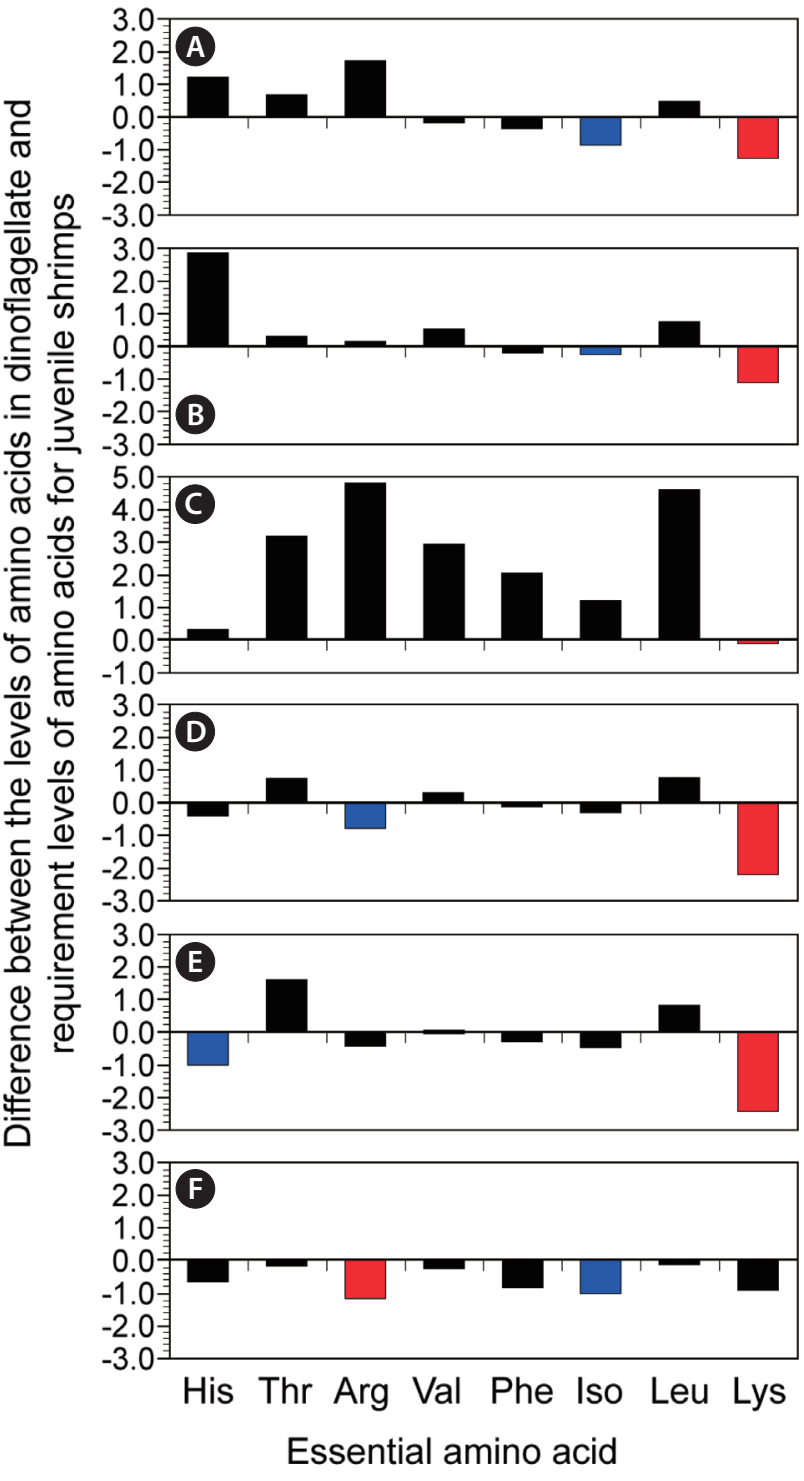

Fig. 3. Difference between the percentages of the essential amino acids that each of six dinoflagellate species possess and those required for juvenile shrimps. (A) Heterocapsa rotundata. (B) Ansanella granifera. (C) Alexandrium andersonii. (D) Takayama tasmanica. (E) Takayama helix. (F) Gymnodinium smaydae. His, hitstidine; Thr, threonine; Arg, arginine; Val, valine; Phe, phenylalanine; Iso, isoleucine; Leu, leucine; Lys, lysine. Red bars indicate the first limiting amino acid and blue bars indicate the second limiting amino acid.

sine were lower than those required (Fig. 3B). In T. tasmanica, the percentages of threonine and leucine were greater than those required, whereas those of arginine and lysine were lower than those required (Fig. 3D). In T. helix, the percentages of threonine and leucine were greater than those required, whereas those of histidine and lysine were lower than those required (Fig. 3E). The first limiting amino acid in $H$. rotundata, A. granifera, A. 
andersonii, T. tasmanica, and T. helix cells was lysine, while that in G. smaydae cells was arginine (Fig. 3). The second limiting amino acid in H. rotundata, A. granifera, and G. smaydae cells was isoleucine, while those of $T$. tasmanica and T. helix cells were arginine and histidine, respectively (Fig. 3).

The EAAI of six dinoflagellate species ranged from 0.79 to 1.59 (Table 3); the EAAI of A. andersonii was the highest, whereas that of G. smaydae was the lowest.

\section{Artemia test for toxicity}

None of the Artemia salina nauplii were dead in wells incubated with high concentrations of $H$. rotundata, A. granifera, T. tasmanica, T. helix, and G. smaydae for $48 \mathrm{~h}$, but 1-2 nauplii were dead when incubated with high concentrations of Alexandrium minutum, which is known to be toxic to Artemia and thus provided a positive control. During the incubation period, abnormal behaviors of the nauplii were not observed.

\section{DISCUSSION}

The percentages of the amount of the $\mathrm{CP}$ relative to dry weight (PPD) of the six dinoflagellates, Heterocapsa rotundata, Ansanella granifera, Alexandrium andersonii, Takayama tasmanica, Takayama helix, and Gymnodinium smaydae tested in the present study fell within the range of other reported dinoflagellates (6.0-71.9\%); $71.9 \%$ for the phototrophic dinoflagellate Prorocentrum triestinum but $6.0-21.5 \%$ for the phototrophic dinoflagellates Amphidinium carterae, Prorocentrum rhathymum, and Symbiodinium sp. (Okaichi 1974, Shah et al. 2016) (Fig. 4). Thus, the PPD of the dinoflagellates tested in this study were greater than that of the phototrophic dinoflagellates except for P. triestinum in the literature. Moreover, the PPD of the dinoflagellates except for $A$. andersonii tested in this study are greater than those of the other microalgal groups Chlorella sp., Tetraselmis suecica, Tetraselmis chui, Isochrysis galbana, Pavlova lutheri, Phaeodactylum tricornutum, Chaetoceros calci-

Table 3. Amino acid profile and essential amino acid index (EAAI) of the dinoflagellates

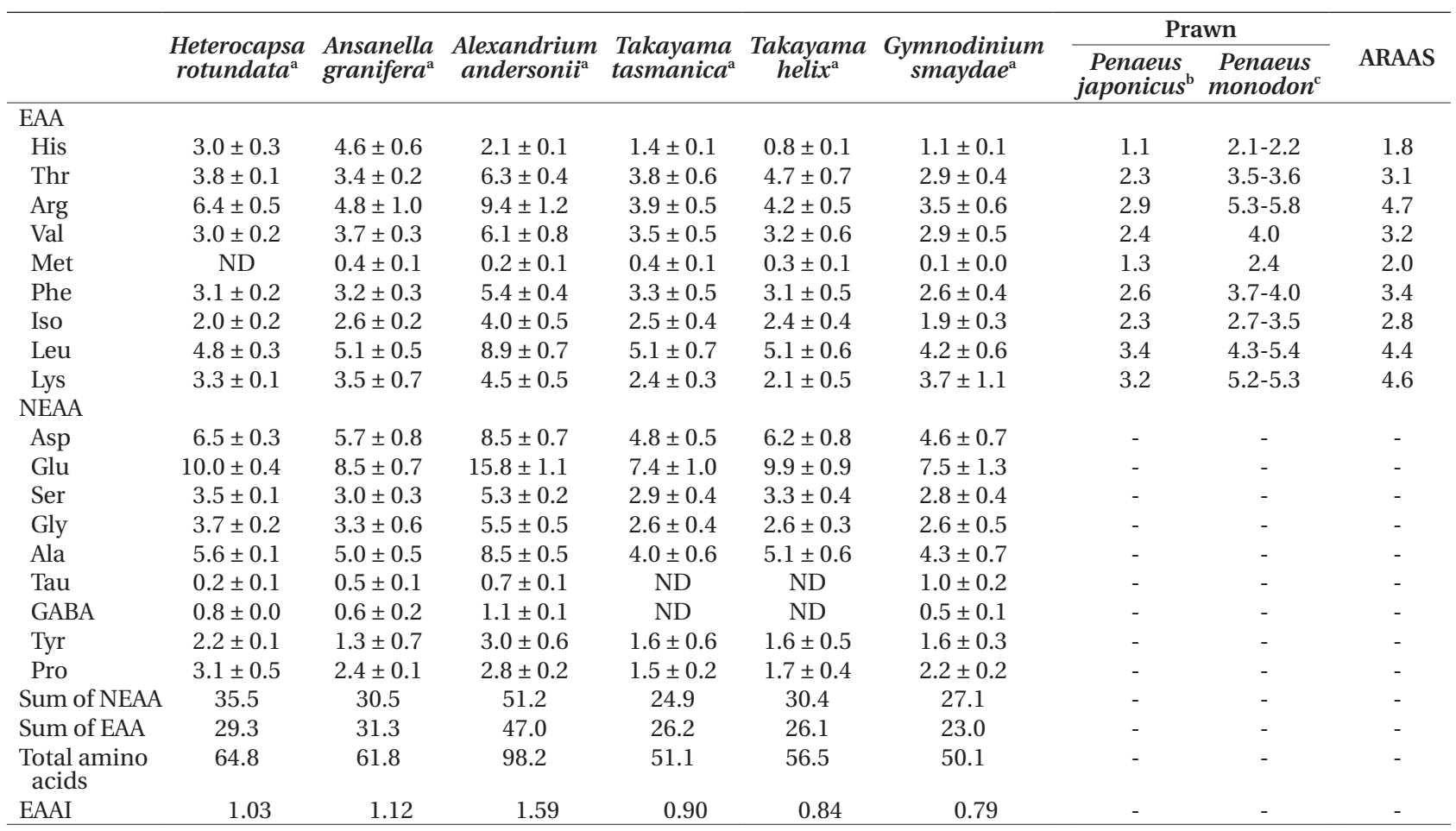

Reference: ${ }^{\mathrm{a}}$ This study; ${ }^{\mathrm{b}}$ Teshima et al. (2002); ${ }^{\mathrm{C}}$ kkiyama (1992), Millamena et al. (1996, 1997, 1998, 1999). Amino acid concentrations are expressed as a percentage of amino acid in crude protein (mean \pm standard deviation).

ARAAS, average requirement of amino acid for shrimp; EAA, essential amino acids; NEAA, nonessential amino acid; ND, not detected, methionine was either not detected or detected in trace amounts because of the hydrolytic condition; His, histidine, Thr, threonine, Arg, arginine and it is considered as an essential amino acid for prawns; Val, valine; Met, methionine; Phe, phenylalanine; Iso, isoleucine; Leu, leucine; Lys, lysine; Asp, aspartic acid; Glu, glutamic acid; Ser, serine; Gly, glycine; Ala, alanine; Tau, taurine; GABA, gamma-aminobutyric acid; Tyr, tyrosine; Pro, proline. 


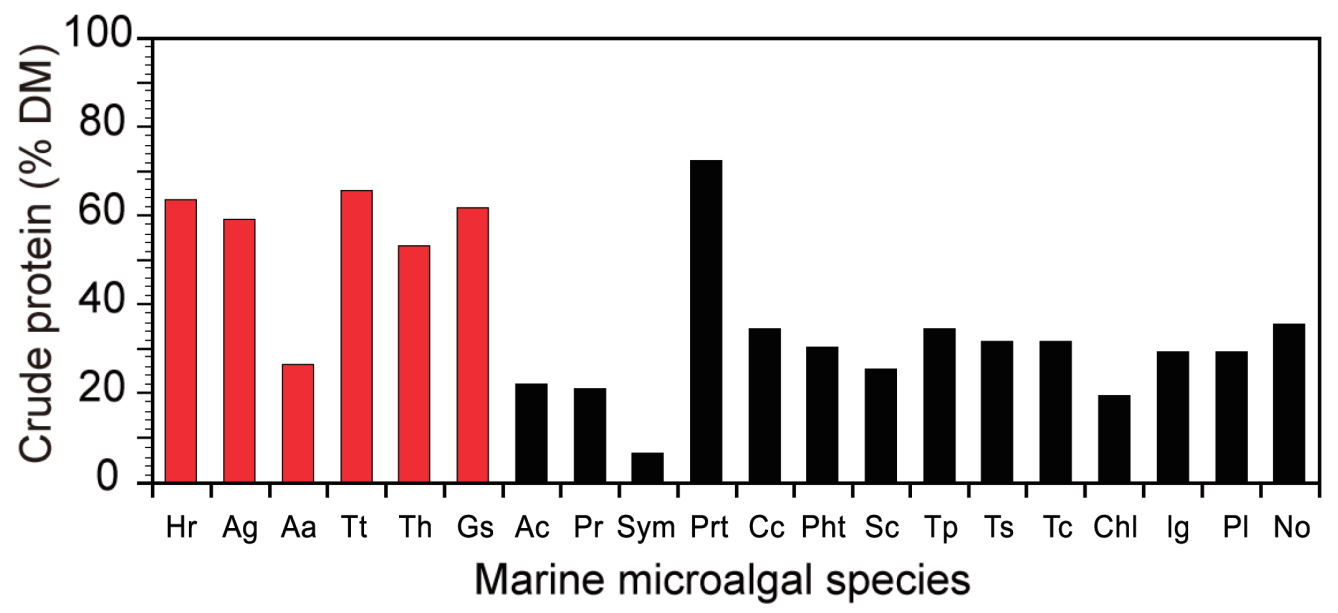

Fig. 4. Comparison of the crude protein contents between the six dinoflagellates tested in the present study and other reported marine microalgae. Crude protein is represented as a percentage of dry mass (DM). Hr, Heterocapsa rotundata; Ag, Ansanella granifera; Aa, Alexandrium andersonii; Tt, Takayama tasmanica; Th, Takayama helix; Gs, Gymnodinium smaydae; Ac, Amphidinium carterae; Pr, Prorocentrum rhathymum; Sym, Symbiodinium sp.; Prt, Prorocentrum triestinum; Cc, Chaetoceros calcitrans; Pht, Phaeodactylum tricornutum; Sc, Skeletonema costatum; Tp, Thalassiosira pseudonana; Ts, Tetraselmis suecica; Tc, Tetraselmis chui; Chl, Chlorella sp.; Ig, Isochrysis galbana; Pl, Pavlova lutheri; No, Nannochloropsis oculata. Red bars indicate the data obtained from this study and black bars indicate data from Brown (1991), Brown and Jeffrey (1992), Okaichi (1974), and Shah et al. (2016).

trans, Nannochloropsis oculata, Skeletonema costatum, and Thalassiosira pseudonana that are most frequently used for aquaculture feeds (19-35\%) (Fig. 4) (Brown 1991, Brown and Jeffrey 1992, Spolaore et al. 2006, Hemaiswarya et al. 2011). In particular, the PPD of T. tasmanica is greater than that of any microalgae except for P. triestinum.

Interestingly, taurine and gamma-aminobutyric acid were not detected in either T. tasmanica or T. helix (family Brachidiniaceae), whereas they were detected in $H$. rotundata (Heterocapsaceae), A. granifera (Suessiaceae),
A. andersonii (Ostreopsidaceae), and G. smaydae (Gymnodiniaceae). Therefore, the absence of taurine and gamma-aminobutyric acid may be a unique character of the species in the family Brachidiniaceae. Taurine is considered to be conditionally essential to shrimps (National Research Council 2011). Therefore, all the dinoflagellates except T. tasmanica and T. helix may be useful diets for shrimps.

Aspartic acid and glutamic acid, two dominant amino acids, were abundant in $H$. rotundata, A granifera, $T$. helix, and G. smaydae as in most microalgae reported

Table 4. Comparison of the essential amino acids between the dinoflagellates and other marine microalgae which are most frequently used for aquaculture

\begin{tabular}{|c|c|c|c|c|c|c|c|c|c|c|c|c|c|c|c|}
\hline & $\mathrm{Hr}$ & Ag & Aa & $\mathrm{Tt}$ & Th & Gs & Cha & $\mathrm{Pt}$ & Sc & Tp & Tet & Iso & Pav & Chl & No \\
\hline His & 4.6 & 7.5 & 2.1 & 2.7 & 1.4 & 2.3 & $1.9-2.4$ & 1.7 & 1.6 & 1.6 & $1.8-2.2$ & $2.0-2.1$ & $1.5-2.0$ & $1.7-1.9$ & 2.1 \\
\hline Thr & 5.8 & 5.5 & 6.4 & 7.5 & 8.3 & 5.9 & $4.5-5.9$ & 5.4 & 5.1 & 5.2 & 4.1-5.3 & $4.5-5.2$ & $4.3-5.2$ & $5.3-5.4$ & 5.5 \\
\hline Arg & 9.7 & 7.7 & 9.6 & 7.6 & 7.5 & 7.0 & $6.4-6.6$ & 6.6 & 6.4 & 6.3 & $13.2-15.0$ & 7.2-7.4 & $8.2-8.4$ & $6.3-6.9$ & 7.3 \\
\hline Val & 4.7 & 6.0 & 6.2 & 6.8 & 5.6 & 5.9 & $5.9-6.2$ & 5.9 & 6.3 & 6.1 & $5.4-5.8$ & $6.1-6.2$ & $6.1-6.7$ & $5.5-6.3$ & 6.5 \\
\hline Phe & 4.8 & 5.3 & 5.5 & 6.4 & 5.5 & 5.2 & $6.7-7.1$ & 6.6 & 6.4 & 6.8 & $5.4-6.1$ & $6.2-6.3$ & $6.0-6.6$ & $5.6-6.0$ & 6.2 \\
\hline Iso & 3.1 & 4.2 & 4.1 & 5.0 & 4.2 & 3.7 & $5.5-5.8$ & 4.9 & 5.2 & 5.5 & $3.5-4.0$ & $4.6-4.8$ & $4.4-4.9$ & $4.2-4.3$ & 4.8 \\
\hline Leu & 7.5 & 8.3 & 9.1 & 10.0 & 9.1 & 8.5 & $7.2-8.2$ & 7.7 & 8.3 & 8.4 & $6.6-8.0$ & 8.7 & $8.1-9.0$ & 7.1-7.4 & 7.8 \\
\hline Lys & 5.1 & 5.6 & 4.6 & 4.7 & 3.8 & 7.3 & $5.1-6.3$ & 5.6 & 5.7 & 5.9 & $5.3-6.0$ & $6.0-6.2$ & $5.6-6.2$ & $6.0-6.3$ & 6.1 \\
\hline
\end{tabular}

Reference: Hr, Ag, Aa, Tt, Th \& Gs, This study; Cha, Pt, Sc, Tp, Iso, Pav \& No, Brown (1991); Tet, Brown (1991), Brown and Jeffrey (1992); Chl, Brown and Jeffrey (1992). The values are percentages (mean) of amino acid in total amino acids. The values in bold indicate the highest values among the percentages of each amino acid of each microalgal species.

$\mathrm{Hr}$, Heterocapsa rotundata; Ag, Ansanella granifera; Aa, Alexandrium andersonii; Tt, Takayama tasmanica; Th, Takayama helix; Gs, Gymnodinium smaydae; Cha, Chaetoceros spp.; Pt, Phaeodactylum tricornutum; Sc, Skeletonema costatum; Tp, Thalassiosira pseudonana; Tet, Tetraselmis spp.; Iso, Isochrysis spp.; Pav, Pavlova spp.; Chl, Chlorella sp.; No, Nannochloropsis oculata; His, histidine; Thr, threonine; Arg, arginine; Val, valine; Phe, phenylalanine; Iso, isoleucine; Leu, leucine; Lys, lysine. 


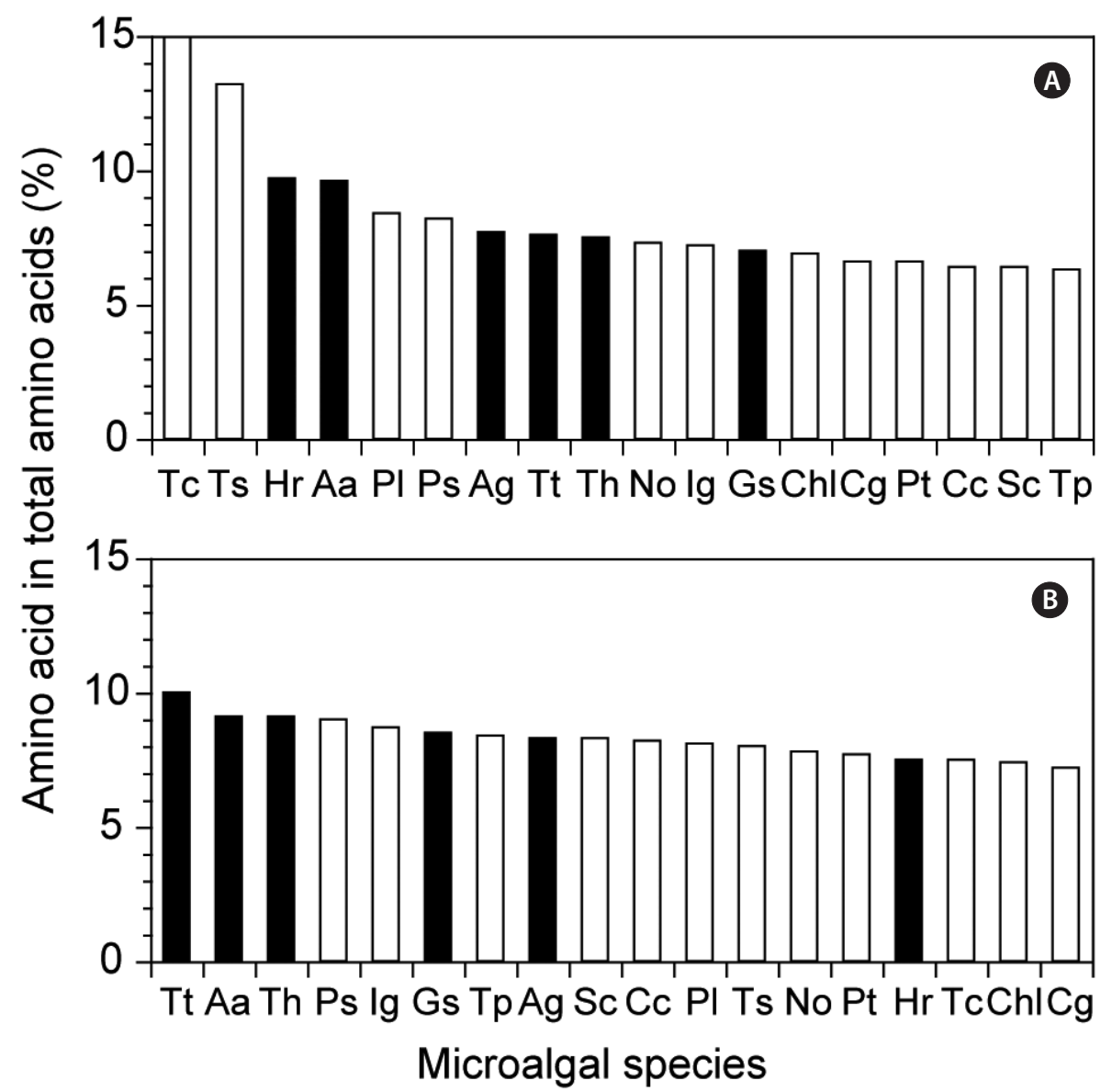

Fig. 5. Comparison of the percentage of arginine (A) and leucine (B) in total amino acids between the six dinoflagellates tested in the present study and other reported marine microalgae. Tc, Tetraselmis chui; Ts, Tetraselmis suecica; Hr, Heterocapsa rotundata; Aa, Alexandrium andersonii; $\mathrm{Pl}$, Pavlova lutheri; Ps, Pavlova salina; Ag, Ansanella granifera; Tt, Takayama tasmanica; Th, Takayama helix; No, Nannochloropsis oculata; Ig, Isochrysis galbana; Gs, Gymnodinium smaydae; Chl, Chlorella sp.; Cg, Chaetoceros gracilis; Pt, Phaeodactylum tricornutum; Cc, Chaetoceros calcitrans; Sc, Skeletonema costatum; Tp, Thalassiosira pseudonana. Black bars indicate the data obtained from this study and white bars indicate data from Brown (1991) and Brown and Jeffrey (1992).

(Brown 1991, Brown and Jeffrey 1992). The percentages of arginine (9.6-9.7\%), the second or third highest amino acid of $H$. rotundata and $A$. andersonii, are greater than that of Chlorella sp., I. galbana, Pavlova salina, P. lutheri, P. tricornutum, Chaetoceros gracilis, C. calcitrans, N. oculata, S. costatum, and T. pseudonana (6.3-8.4\%) but lower than that of T. chui and T. suecica (15.0\% and $13.2 \%$, respectively) (Fig. 5A). Therefore, H. rotundata and A. andersonii can be used for the formulation of arginine-rich mixed algal diets. The percentage of leucine (10.0\%), the second highest in TDAAs of T. tasmanica, is greater than that of the other dinoflagellates (7.5-9.1\%) and the marine microalgae (7.1-9.0\%) (Fig. 5B). Therefore, T. tasmanica may be useful for the formulation of leucine-rich mixed algal diets. Among the reported microalgae, A. granifera has the highest percentage of histidine (7.5\%), and $T$. he- lix has the highest percentage of threonine (8.3\%). T. tasmanica has the highest percentage of valine $(6.8 \%)$, and G. smaydae has the highest percentage of lysine $(7.3 \%)$ (Table 4). Thus, A. granifera, T. helix, T. tasmanica, and G. smaydae can be used for histidine, threonine, valine, and lysine sources, respectively.

The EAAIs of $A$. andersonii, $H$. rotundata, and $A$. granifera (1.03-1.59) can be scored to be 'high quality protein' for animal feeds, that of T. tasmanica 'good quality protein', but those of T. helix and G. smaydae 'useful quality protein'. Therefore, the nutritional values of the protein possessed by all the dinoflagellates tested in the present study are high enough to be used as a food source for the shrimps represented here. The EAAIs of $A$. andersonii, $H$. rotundata, and $A$. granifera are greater than that of Chlorella spp. and T. chui (0.84-0.91) (Brown and Jef- 
frey 1992) which have been used for animal feeds in the aquaculture industry.

The presence or absence of toxic materials can affect the use of target microalga as an animal feed. The strains of $A$. andersonii and the other five dinoflagellates tested in the present study were revealed not to be toxic to brine shrimp Artemia salina (Kim et al. 2017). Therefore, these dinoflagellate strains in the present study can be used as a food source of shrimps.

To use dinoflagellates commercially as animal feeds, they should be cultivated at a large scale. The methods of cultivating each of A. andersonii, A. granifera, G. smaydae, $H$. rotundata, T. helix, and T. tasmanica have been developed; the mixotrophic growth rates of $A$. andersonii, A. granifera, G. smaydae, and T. helix on optimal prey species are considerably greater than their autotrophic growth without prey (Lee et al. 2014b, 2016, Jeong et al. 2016, Lim et al. 2018). Using suitable prey, these mixotrophic dinoflagellates can be easily cultivated. The growth rates of these dinoflagellates may be elevated if they are cultivated in optimal light, temperature, salinity, and nutrient conditions. Thus, it is worthwhile to explore the optimal conditions for each dinoflagellate species.

The dinoflagellates tested in the present study have useful materials other than amino acids; $A$. granifera has beta-carotene (Jeong et al. 2014), T. tasmanica and T. helix have violaxanthin and / or fucoxanthin (de Salas et al. 2003), and G. smaydae has zeaxanthin (Kang et al. 2014). Astaxanthin, a metabolite of zeaxanthin, is incorporated into the diets of some fish, shrimp, and lobster for muscle color (Gouveia et al. 2008). Therefore, the dinoflagellates tested in the present study could be used for providing useful amino acids with useful pigments to animals in the aquaculture industry.

\section{ACKNOWLEDGEMENTS}

This work was supported by the Useful Dinoflagellate Program of Korea Institute of Marine Science and Technology Promotion (KIMST) funded by the Ministry of Oceans and Fisheries (MOF), development of the methods for controlling and managing marine ecological disturbance causing and harmful organisms (MEDHO) of KIMST, and the National Research Foundation of Korea Grant funded by the Korea Government/MICTFP (NRF2010-0020702 and NRF-2012R1A2A2A01010987) award to $\mathrm{HJJ}$.

\section{REFERENCES}

Akiyama, D. M. 1992. Future considerations for shrimp nutrition and the aquaculture feed industry. In Wyban, J. (Ed.) Proc. Special Session on Shrimp Farming, World Aquaculture Society, Baton Rouge, LA, pp. 198-205.

Andersen, R. 2013. The microalgal cell. In Richmond, A. \& $\mathrm{Hu}, \mathrm{Q}$. (Eds.) Handbook of Microalgal Cultures: Applied Phycology and Biotechnology. 2nd ed. Wiley Blackwell, West Sussex, pp. 3-20.

Becker, W. 2004. Microalgae in human and animal nutrition. In Richimond, A. (Ed.) Handbook of Microalgal Culture: Biotechnology and Applied Phycology. Blackwell Publishing Ltd., Oxford, pp. 312-351.

Bleakley, S. \& Hayes, M. 2017. Algal proteins: extraction, application, and challenges concerning production. Foods 6:33.

Borowitzka, M. A. 1997. Microalgae for aquaculture: opportunities and constraints. J. Appl. Phycol. 9:393.

Brown, M. R. 1991. The amino-acid and sugar composition of 16 species of microalgae used in mariculture. J. Exp. Mar. Biol. Ecol. 145:79-99.

Brown, M. R. 2002. Nutritional value and use of microalgae in aquaculture. In Cruz-Suárez, L. E., Ricque-Marie, D., Tapia-Salazar, M., Gaxiola-Cortés, M. G. \& Simoes, N. (Eds.) Advances en Nutrición Acuícola VI. Memorias del VI Simposium Internacional de Nutrición Acuícola, Universidad Autónoma de Nuevo León, Monterrey, pp. 281-292.

Brown, M. R. \& Jeffrey, S. W. 1992. Biochemical composition of microalgae from the green algal classes Chlorophyceae and Prasinophyceae. 1. Amino acids, sugars and pigments. J. Exp. Mar. Biol. Ecol. 161:91-113.

Buono, S., Langellotti, A. L., Martello, A., Rinna, F. \& Fogliano, V. 2014. Functional ingredients from microalgae. Food Funct. 5:1669-1685.

de Salas, M. F., Bolch, C. J. S., Botes, L., Nash, G., Wright, S. W. \& Hallegraeff, G. M. 2003. Takayama gen. nov. (Gymnodiniales, Dinophyceae), a new genus of unarmored dinoflagellates with sigmoid apical grooves, including the description of two new species. J. Phycol. 39:1233-1246.

Fabregas, J. \& Herrero, C. 1985. Marine microalgae as a potential source of single cell protein (SCP). Appl. Microbiol. Biotechnol. 23:110-113.

Flynn, K. J. \& Flynn, K. 1992. Non-protein free amines in microalgae: consequences for the measurement of intracellular amino acids and of the glutamine/glutamate ratio. Mar. Ecol. Prog. Ser. 89:73-79.

Gouveia, L., Batista, A. P., Sousa, I., Raymundo, A. \& Bandarra, N. M. 2008. Microalgae in novel food products. 
In Papadopoulos, K. N. (Ed.) Food Chemistry Research Developments. Nova Science Publishers, New York, pp. 75-112.

Guillard, R. R. L. \& Ryther, J. H. 1962. Studies of marine planktonic diatoms: I. Cyclotella nana Hustedt, and Detonula confervacea (Cleve) Gran. Can. J. Microbiol. 8:229-239.

Guiry, M. D. \& Guiry, G. M. 2018. AlgaeBase. World-wide electronic publication, National University of Ireland, Galway. Available from: http://www.algaebase.org. Accessed Sep 10, 2018.

Harel, M. \& Clayton, D. 2004. Feed formulation for terrestrial and aquatic animals. U.S. Patent No. 20070082008 (WO/2004/080196). U.S. Patent and Trademark Office, Washington, DC.

Hayashi, T., Suitani, Y., Murakami, M., Yamaguchi, K., Konosu, S. \& Noda, H. 1986. Protein and amino acid compositions of five species of marine phytoplankton. Bull. Jpn. Soc. Sci. Fish. 52:337-343.

Hemaiswarya, S., Raja, R., Kumar, R. R., Ganesan, V. \& Anbazhagan, C. 2011. Microalgae: a sustainable feed source for aquaculture. World J. Microbiol. Biotechnol. 27:1737-1746.

Holmes, M. J., Brust, A. \& Lewis, R. J. 2014. Dinoflagellate toxins: an overview. In Botana, L. M. (Ed.) Seafood and Freshwater Toxins: Pharmacology, Physiology, and Detection. 3rd. Vol. 1. CRC Press, Boca Raton, FL, pp. 3-38.

Jang, S. H., Jeong, H. J. \& Kwon, J. E. 2017. High contents of eicosapentaenoic acid and docosahexaenoic acid in the mixotrophic dinoflagellate Paragymnodinium shiwhaense and identification of putative omega-3 biosynthetic genes. Algal Res. 25:525-537.

Jeong, H. J., Jang, S. H., Moestrup, Ø., Kang, N. S., Lee, S. Y., Potvin, E. \& Noh, J. H. 2014. Ansanella granifera gen. et sp. nov. (Dinophyceae), a new dinoflagellate from the coastal waters of Korea. Algae 29:75-99.

Jeong, H. J., Lim, A. S., Franks, P. J. S., Lee, K. H., Kim, J. H., Kang, N. S., Lee, M. J., Jang, S. H., Lee, S. Y., Yoon, E. Y., Park, J. Y., Yoo, Y. D., Seong, K. A., Kwon, J. E. \& Jang, T. Y. 2015. A hierarchy of conceptual models of red-tide generation: nutrition, behavior, and biological interactions. Harmful Algae 47:97-115.

Jeong, H. J., Ok, J. H., Lim, A. S., Kwon, J. E., Kim, S. J. \& Lee, S. Y. 2016. Mixotrophy in the phototrophic dinoflagellate Takayama helix (family Kareniaceae): predator of diverse toxic and harmful dinoflagellates. Harmful Algae 60:92-106.

Jeong, H. J., Yoo, Y. D., Kim, J. S., Seong, K. A., Kang, N. S. \& Kim, T. H. 2010. Growth, feeding, and ecological roles of the mixotrophic and heterotrophic dinoflagellates in marine planktonic food webs. Ocean Sci. J. 45:65-91.
Kang, N. S., Jeong, H. J., Moestrup, Ø., Lee, S. Y., Lim, A. S., Jang, T. Y., Lee, K. H., Lee, M. J., Jang, S. H., Potvin, É., Lee, S. K. \& Noh, J. H. 2014. Gymnodinium smaydae n. sp., a new planktonic phototrophic dinoflagellate from the coastal waters of western Korea: morphology and molecular characterization. J. Eukaryot. Microbiol. 61:182-203.

Kim, J. H., Jeong, H. J., Lim, A. S., Kwon, J. E., Lee, K. H., Park, K. H. \& Kim, H. S. 2017. Removal of two pathogenic scuticociliates Miamiensis avidus and Miamiensis sp. using cells or culture filtrates of the dinoflagellate Alexandrium andersonii. Harmful Algae 63:133-145.

LaJeunesse, T. C., Parkinson, J. E., Gabrielson, P. W., Jeong, H. J., Reimer, J. D., Voolstra, C. R. \& Santos, S. R. 2018. Systematic revision of Symbiodiniaceae highlights the antiquity and diversity of coral endosymbionts. Curr. Biol. 28:2570-2580.

Lee, K. H., Jeong, H. J., Jang, T. Y., Lim, A. S., Kang, N. S., Kim, J. -H., Kim, K. Y., Park, K. -T. \& Lee, K. 2014a. Feeding by the newly described mixotrophic dinoflagellate Gymnodinium smaydae: feeding mechanism, prey species, and effect of prey concentration. J. Exp. Mar. Biol. Ecol. 459:114-125.

Lee, K. H., Jeong, H. J., Kwon, J. E., Kang, H. C., Kim, J. H., Jang, S. H., Park, J. Y., Yoon, E. Y. \& Kim, J. S. 2016. Mixotrophic ability of the phototrophic dinoflagellates Alexandrium andersonii, A. affine, and A. fraterculus. Harmful Algae 59:67-81.

Lee, S. K., Jeong, H. J., Jang, S. H., Lee, K. H., Kang, N. S., Lee, M. J. \& Potvin, É. 2014b. Mixotrophy in the newly described dinoflagellate Ansanella granifera: feeding mechanism, prey species, and effect of prey concentration. Algae 29:137-152.

Lim, A. S., Jeong, H. J., Kim, J. H. \& Lee, S. Y. 2015. Description of the new phototrophic dinoflagellate Alexandrium pohangense sp. nov. from Korean coastal waters. Harmful Algae 46:49-61.

Lim, A. S., Jeong, H. J., Ok, J. H. \& Kim, S. J. 2018. Feeding by the harmful phototrophic dinoflagellate Takayama tasmanica (Family Kareniaceae). Harmful Algae 74:19-29.

Lourenço, S. O., Barbarino, E., Lavín, P. L., Marquez, U. M. L. \& Aidar, E. 2004. Distribution of intracellular nitrogen in marine microalgae: calculation of new nitrogen-toprotein conversion factors. Eur. J. Phycol. 39:17-32.

Madrigal, R. F. D. A. G., da Silva, U. D. A. T., Tavares, C. P. D. S. \& Ballester, E. L. C. 2017. Use of native and non-native shrimp (Penaeidae, Dendrobranchiata) in world shrimp farming. Rev. Aquac. https://doi.org/10.1111/ raq.12206.

Markell, D. A. \& Trench, R. K. 1993. Macromolecules exuded 
by symbiotic dinoflagellates in culture: amino acid and sugar composition. J. Phycol. 29:64-68.

Matos, J., Cardoso, C., Bandarra, N. M. \& Afonso, C. 2017. Micoalgae as healthy ingredients for functional food: a review. Food Funct. 8:2672-2685.

Menden-Deuer, S. \& Lessard, E. J. 2000. Carbon to volume relationships for dinoflagellates, diatoms, and other protist plankton. Limnol. Oceanogr. 45:569-579.

Mendes, A., Reis, A., Vasconcelos, R., Guerra, P. \& da Silva, T. L. 2009. Crypthecodinium cohnii with emphasis on DHA production: a review. J. Appl. Phycol. 21:199-214.

Millamena, O. M., Bautista, M. N., Reyes, O. S. \& Kanazawa, A. 1997. Threonine requirement of juvenile marine shrimp Penaeus monodon. Aquaculture 151:9-14.

Millamena, O. M., Bautista-Teruel, M. N. \& Kanazawa, A. 1996. Methionine requirement of juvenile tiger shrimp Penaeus monodon Fabricius. Aquaculture 143:403-410.

Millamena, O. M., Bautista-Teruel, M. N., Reyes, O. S. \& Kanazawa, A. 1998. Requirements of juvenile marine shrimp, Penaeus monodon (Fabricius) for lysine and arginine. Aquaculture 164:95-104.

Millamena, O. M., Teruel, M. B., Kanazawa, A. \& Teshima, S. 1999. Quantitative dietary requirements of postlarval tiger shrimp, Penaeus monodon, for histidine, isoleucine, leucine, phenylalanine and tryptophan. Aquaculture 179:169-179.

Muller-Feuga, A. 2013. Microalgae for aquaculture: the current global situation and future trends. In Richmond, A. \& Hu, Q. (Eds.) Handbook of Microalgal Cultures: Applied Phycology and Biotechnology. 2nd ed. Wiley Blackwell, West Sussex, pp. 615-627.

National Research Council. 2011. Nutrient requirements of fish and shrimp. National Academies Press, Washington, DC, 376 pp.

Norton, T. A., Melkonian, M. \& Andersen, R. A. 1996. Algal biodiversity. Phycologia 35:308-326.

Okaichi, T. 1974. Significance of amino acid composition of phytoplankton and suspensoid in marine biological production. Bull. Jpn. Soc. Sci. Fish. 40:471-478.

Onodera, K., Konishi, Y., Taguchi, T., Kiyoto, S. \& Tominaga, A. 2014. Peridinin from the marine symbiotic dinoflagellate, Symbiodinium sp., regulates eosinophilia in mice. Mar. Drugs 12:1773-1787.

Oser, B. L. 1959. An integrated essential amino acid index for predicting the biological value of proteins. In Albanese, A. A. (Ed.) Amino Acid Nutrition. Academic Press, New York, pp. 295-311.

Pulz, O. \& Gross, W. 2004. Valuable products from biotechnology of microalgae. Appl. Microbiol. Biotechnol. 65:635-648.

Rosic, N. N. \& Dove, S. 2011. Mycosporine-like amino acids from coral dinoflagellates. Appl. Environ. Microbiol. 77:8478-8486.

Roy, S. S. \& Pal, R. 2015. Microalgae in aquaculture: a review with special references to nutritional value and fish dietetics. Proc. Zool. Soc. 68:1-8.

Sánchez, R. M. 1986. Rearing of misid stages of Penaeus vannamei fed cultured algae of three species. Aquaculture 58:139-144.

Shah, M. R., Samarakoon, K. W., An, S. -J., Jeon, Y. -J. \& Lee, J. -B. 2016. Growth characteristics of three benthic dinoflagellates in mass culture and their antioxidant properties. J. Fish. Aquat. Sci. 11:268-277.

Shimizu, Y. 1996. Microalgal metabolites: a new perspective. Annu. Rev. Microbiol. 50:431-465.

Singh, J. \& Gu, S. 2010. Commercialization potential of microalgae for biofuels production. Renew. Sustain. Energ. Rev. 14:2596-2610.

Singh, J. \& Saxena, R. C. 2015. An introduction to microalgae: diversity and significance. In Kim, S. -K. (Ed.) Handbook of Marine Microalgae: Biotechnology Advances. Academic Press, San Diego, CA, pp. 11-24.

Spolaore, P., Joannis-Cassan, C., Duran, E. \& Isambert, A. 2006. Commercial applications of microalgae. J. Biosci. Bioeng. 101:87-96.

Taylor, F. J. R., Hoppenrath, M. \& Saldarriaga, J. F. 2008. Dinoflagellate diversity and distribution. Biodivers. Conserv. 17:407-418.

Teshima, S., Alam, M. S., Koshio, S., Ishikawa, M. \& Kanazawa, A. 2002. Assessment of requirement values for essential amino acids in the prawn, Marsupenaeus japonicus (Bate). Aquac. Res. 33:395-402.

Zhang, T., Chi, Z. \& Sheng, J. 2009. A highly thermosensitive and permeable mutant of the marine yeast Cryptococcus aureus G7a potentially useful for single-cell protein production and its nutritive components. Mar. Biotechnol. 11:280-286. 